\title{
Governance and Corruption in Nigeria: A Philo-Psychological Management Analysis
}

\author{
Samuel Asuquo Ekanem, PhD, Llb (Hons),BI \\ Department of Educational Foundations and Administration, \\ Cross River University of Technology, Calabar, Nigeria. \\ Ekeng Nyong Ekefre,PhD \\ Department of Educational Foundations and Administration, \\ Cross River University of Technology, Calabar, Nigeria.
}

\section{Doi:10.5901/mjss.2013.v4n14p141}

\section{Abstract}

The menace of corruption in Nigeria is very pervasive with global implications. So pervasive is corruption in Nigeria that almost every aspect of national life is affected one way or the other. The present magnitude of corruption in Nigeria is traceable to the many years of military rule where due process was not observed in public procurement and contract bidding. Both the private and public sectors of the country are affected by various forms of corruption. As a consequence, the impact of governance in the country is impeded and if a check is not put in place, Nigeria will be left behind in the development agenda of world bodies. It is a trite fact that corruption in one place is connected to others, and enabled by systems of weak regulations and poor oversight. Human societies have been known to be bedeviled by corruption but some have been able to combat this menace by putting statutes in place to criminalize corruption and ensuring that enforcement mechanisms are enabled to act. This paper, therefore explores public and private sector governance in Nigeria with a view to exposing the various forms of corruption in the country. The paper took the position that corruption plays a dominant role in the development deficit in the country and examined the philosophical and psychological reasons for corruption. The paper also x-rayed the devastating effects of corruption which includes underdevelopment, negative image of the country, and impact on the global market, the paper concludes by questioning the existing anti-corruption strategies in the country and proposed the way they can be made to work.

\section{History of Corruption in Nigeria}

Historically, it is difficult to provide the exact date when corruption became a subject of national discourse in Nigeria. This difficulty stemmed from two important facts that corruption is as old as society, and the complex nature of the evolution of the Nigerian state. However, Faseke (2006) traced the festering corruption within the civil service and its consequent hindrance to performance of its bureaucratic function to the nation, to the British Colonial legacy inherited by Nigeria. He posits that "the transformation of the civil service from an instrument of exploitation in the colonial era to one of corruption and fraud in post-independence period especially under military rule that created job insecurity the origin of corruption in Nigeria".

Historically therefore, Faseke (2006) asserts:

....under the British colonial administration, the civil service ... served the interest of the colonial overlords and structured to perpetuate colonial economic imperialism given that, the Nigerian economy (as a satellite of the British economy) was meant to generate surplus for metropolitan power through the supply of cheap raw materials for the British industries in return for manufacturers with the terms of trade continually against Nigeria (103).

It is clear that the civil service was structured for exploitative purpose; hence, it becomes an easy tool of corruption during the post-colonial epoch. This can be seen in the social distance that existed between the higher civil servants and their subordinates on the one hand as well as the higher civil servants and members of the public on the other hand (Feseke, 206). This social disparity conferred on the higher civil servants a high class status distinct from the rest civil servants, and this had spiral negative effects on the Nigerian civil service. These higher civil servants until 1950s were mostly Europeans and they had cars, houses and other remarkable incentives that became the hallmarks of the higher civil service and to which the rest were denied. It was on the basis of this that civil servants in the middle and lower 
income cadres struggled and rushed academically for university degrees. The impatient ones among them resorted to cutting corners in a bid to get rich quickly. So, under the guise of venting their angers on the British for dominating Nigerians in their fatherland, civil servants at the middle and lower cadres connived to hide files in a bid to force Nigerians pay before files could be found and treated with the necessary speed. This had negative consequences on the civil service inherited at independence and this laid the foundation for corruption in Nigeria.

The history of government especially, the military government in Nigeria had been a case of sheer "brigandage of stupendous proportion" that depended on corruption due largely to the conniving role of many of the top civil servants, which is played in concert with the military. Military rule coincided with the oil boom of the 1970s that paved way for large public works and constructions, which is unparallel in the socio-economic development of Nigeria. What provided the impetus for the large scale constructions was the rehabilitation and reconstruction policy of the General Yakubu Gowon's regime just after the end of the civil war.

The inexperience of the military in politics and administration compelled the military regime to lean more on the civil service. This situation further bolstered the power of the civil service during the military era. It was on the basis of this that the Nigerian Opinion Magazine in 1972 as quoted by Faseke asserted that "Nigeria was being governed by a military-bureaucratic complex. It was as a result of this that some higher civil servants were referred to as super Permanent Secretaries. This appellation signified a shift in their role and equally of their role - perception by the articulate public.

As a result of this, considerable mismanagement was occasioned through a process whereby the higher senior civil servants served both as chairmen and key board members of public enterprises under their supervision. This dubious practice of transferring civil servants attitudes and practices to industrial and commercial concerns was worsened by the fact that some Permanent Secretaries of the Federal Ministry of Finance were on more than fifty boards at same time (Allison: 109). This according to Daily Times led to the production of a new class of indigenous mandarins.

From the above analyses, it is established that corruption has its root in the civil service. This was made worse with the incessant military coups in the country. With the military at the helm of affairs, there was no respect for the "constitution, rules and due process. Everything was done with military fiat and dispatch. These uniquely cleared the way for corruption to strive in the civil service and top military. This can be seen in the Nigerian Tribune report of $31^{\text {st }}$ October, 1992 where it stated that:

The N4.5 million stolen from the Ministry of Works and Housing in fraud perpetuated by some senior and junior officials of the Ministry has been recovered.

Also, during the Babangida's regime, the Sunday Concord of December 1992 reported that "The Federal Ministry of Works and Housing has sacked sixty nine of the workforce including a deputy director for alleged malpractices. The Minister reported that the malpractices ranged from issuance of fake authority to impersonation, payment of salaries to ghost workers to outright theft of government funds and property.

Between 1985 and 1993 when the Babangida's regime ended, and Abacha became the helmsman, a new trend in corruption was noticed. During this period huge public funds was looted and the predators would set ablaze major building where the looting took place.

To this day, veniality, stealing, large scale fraud, bribery and corruption including other forms of malpractices have eaten deep into the civil service and the fabric of the Nigerian society. This can be seen in the large scale frauds perpetuated by the civilian government in the various states in Nigeria. These corrupt practices have permeated the entire spectrum of the Nigerian system. Indeed, the military it has been argued institutionalized corruption in Nigeria, hence, the civilian government from 1999 to date has carried on the corrupt practices in diverse ways. The depth of corruption as social ills can be seen in the huge budgetary allocation by government of the three tiers without a corresponding development of infrastructure and social services such as education, health, electricity and transportation.

The worst scenario is the involvement of the legislative arm of government and the judiciary in the executive corrupt practices. This can be seen the statement credited to General Ishola Williams of Transparency International when he complained that "judges are using the tribunals to make money. All those who have gone through election tribunals are multi-millionaires today" (The Nation, June 20, 2010). Also, Ayoade (2011) graphically captured the legislative involvement in the corruption fever when he states that:

The National Assembly has orchestrated a sumptuous self remuneration that forced former president Obasanjo to blow the whistle. He indicated that it costs N250m to maintain one single senator annually. For him, this is excessive and unsustainable. It is a quick kill in slow motion and what Femi Falana describes as "probative prodigality." Honourable Ali Ndume, the minority leader of the House of Representatives did not contradict Obasanjo. He only said that Obasanjo lacked the moral right to complain about it because he is the "godfather of corruption". The National Assembly has taken 
undue control of the instrument of wealth transfers to institute a resource capture and thus maximize its hare of wealth transfer. Considering the parlour state of economy and relative penury of the Nigerian worker the self service award by members of the National Assembly is a gross misdemenaour and abuse of public trust. That the members continue to defend the outrageous remuneration is evidence of their capacity for pathological behaviour (38). states that:

Corruption from the above view has grown to the point of doctrine. This view is shared by Ayoade (2011) when he

In the 1960's the Yorubas were wooed with such bread and butter strategies. Such campaigns proceeded by corrupting how much the Yoruba lost by being in opposition. Thus people are invited to the federal table ... The implications are a life of ease and sharing of the national cake as it were...

\title{
2. Common forms of Corruption
}

Corruption is a very complex phenomenon that affects a country in diverse ways. These effects of corruption are however dependent on the forms of corruption that is prevalent in a given society. Therefore, as there are several effects of corruption, so are there several forms of corruption.

This graphically presents the broad spectrum of corruption as a systemic and unethical conduct, which we can categorized as political corruption, judicial corruption, rigging, contract inflation and kickbacks, bribery, fraud of diverse kinds, embezzlement, nepotism and cronyism.

\subsection{Political Corruption}

Political corruption is one of the common forms of corruption that occur in almost every country. This involves applying unethical and illegal means within the political system, structural or institution. Within the political realm, corruption undermines democracy and good governance through the flouting or even subverting formal processes. Political corruption can easily be seen during elections in Nigeria. This occurs through rigging, which is achieved by multiple thumb-printing, stuffing of ballot boxes, falsification of results among others. An electoral fraud is indeed one of the greatest challenges of Nigeria hence, Ekanem (2010) call on Nigerian politicians to:

\begin{abstract}
... try hard enough to allow for a smooth operation of the rule of law. This will guarantee the rights of the individual. The various arms of government will under the rule of law function effectively without creating any legal vacuum which will create anarchic situations like was the case during the "little to the right and a little to the left experiment of the IBB era. When there is the presence of the rule of law, the effect will be that, government will become democratic because it is laid on the foundation of the consent of the people. This shows that legitimacy is earned through the due process of law, which makes mass participation of the people possible and popular sovereignty ensured.
\end{abstract}

What can be gleaned from this is that electoral fraud destroys and denies the government legitimacy. It hampers mass participation of the people in the electoral processes. This can be seen in the general apathy shown by Nigerians in the 1993, 1999, 2003 and 2007 general elections. People refused to go out to vote because of the firm belief that votes will not count. It was therefore on the basis of this that the "one man one vote" and "votes must count" slogans become a selling political campaign and strategy.

However, whenever there is the absence of these basic principles of democracy that also recognize the sanctity of "human person" and the protection of his rights, the result will be conflict, distruct, disunity, selfishness, dishonesty, injustice and underdevelopment. These happen because the politicians owe the people no commitment hence the looting of the public treasury. Mordi (2010) put it thus:

From the time of our independence in 1960 this mindless looting of state treasury has developed into a system with pattern and purpose. It has become an institution with a soul... curiously that eras provided the country with some proven cases of corrupt enrichment of public offers. Nigeria's first panel of inquiry set up to look into a case of corruption in public life was that which investigated the African Continental Bank - Nnamdi Azikiwe affair.... Incidences of widespread corruption were uncovered in 1967 when another commission of enquiry was instituted to investigate assets of 15 public officers in the defunct mid-western region... it is instructive that major Kaduna Nzeogwu and his colleagues identified corruption as the main reason why they staged the first military coup d'état in Nigeria on January 15, 1966.

It was therefore on the basis of this that the aim of the revolutionary council was to establish a strong, united and prosperous nation, free from corruption and internal strife, hence Nzeogwu (1966) stated that "Our enemies are political profiteers, swindlers, the man in high and low places that seek to keep the country divided permanently, so that they can 
remain in the office as ministers and VIPs of waste..."

Chinua Achebe shares this sentiment when he asserts that the political thoughts of both Azikiwe and Awolowo were based on politics for material gain.

So, even the usurpation of political power in January, 1966 by the military, a culture of corruption had already been widespread, though not so brazen among the political class. The subsequent military that seized power always cited corruption as a reason for their intervention. However, military regimes always become more corrupt than the one they claimed to correct. Despotism, which was entrenched and characteristics of military regimes completely destroyed the culture of accountability and enthroned uncontrolled power and encouraged influence peddling.

Over the years, corruption in Nigeria has become widespread that create an enabling environment for organized crimes and bad governance. Ribadu graphically painted the current state of political corruption in Nigeria when he said:

\begin{abstract}
... between 1960 and 1999 Nigerian officials had stolen or wasted more than $\$ 40$ billion dollars. That is six times the Marshal plan, the total sum needed to rebuild a devastated Europe in the aftermath of the Second World War. When you look across a nation and a continued riddled with poverty and weak institutions; and you think of what this money could have done - only then can you truly understand the crime of corruption, and the almost inhumane indifference that is required by those who wield it for personal gain.
\end{abstract}

It is clear from this that political corruption has the most devastating effect on the people. It robbed the people of their common patrimony and deprives the present and future generations of their rights to development and self actualization. For instance, the Delta Steel Company was sold to a company that did not participate in the bid. Ajakunta steel complex worth over two hundred billion dollars was sold for less than one hundred billion naira.

Olorode (2011) presented this more graphically when he says:

From some of the information available to the public, the Nigerian privatization project, aside from rubbishing thousands of workers, is nothing short of an open robbery as pillage of our collective patrimony. This has been made possible by the privatization beneficiaries and their friends directly linked with the political power brokers and manipulators of the public treasury.

It is this high rate of deprivation of the people by the political class that prompted the President of Academic Staff Union of Universities (ASUU), Professor Awouzie to declare that:

It is condemnable that the ruling class politicians have not given up their culture of conducting politics as warfare. This cases of rigging, ballot snatching, political assimilation, violence, underage voting, and intimidation of voters were observed new forms of dangerous electoral behaviour also emerged. For example, some political parties resorted to buying the cards of voters to prevent them from casting their votes for their opponents. The condemnable role of money in shaping electoral outcomes was observed in many places.

From this, we discover that political corruption is becoming more dynamic and diversified.

\title{
2.2 Judicial Corruption
}

The judiciary was once viewed as the last hope of the common man. However, this "last hope" tag of the judiciary appears to be a fallacy of imagery in recent times. This is because of the unethical and illegal activities that go on in our judicial system. Indeed, corruption has found its way into the judiciary and the confidence of the people in the judiciary as the "last hope" of the common has been eroded. Corruption in the judiciary compromises the rule of law. This can be seen in the words of Ogbu (2011) when he writes:

The high courts, however, have been a stumbling block in the fight against corruption through the abuse of their power to grant injunctions. An Abuja High Court on December 31, 2003 restrained ICPC and the Attorney General of the Federation from investigating allegations of financial impropriety level against the former speaker of the House of Representatives, Alhaji Ghali Na'Abba, pending the determination of the substantive suit. The injunction was granted based on an exparte motion.

Again, in 2001, the Senate set up the Oyofo committee to investigate the alleged cases of impropriety in the award of contracts by the National Assembly. The indicted Senators obtained a court injunction restraining the Attorney General of the Federation, the Inspector General of Police, and the Senate from arresting or initiating criminal proceedings against them. We can see the presence of corruption in the Nigerian judicial system through the recurrent case where 
senior Advocates of Nigeria, Kayode Adetokunbo and Daniel Dodo, were arraigned in an Abuja High Court for offering gratification to some officers of the Independent National Electoral Commission. On that same day of their arraignment, the High Court suo motu discharged them without reasonable grounds. Though ICPC has appealed against the discharge but how far, will the appeal go within the same system?

The courts in Nigeria in a number of cases had rendered interpretations that tend to protect corrupt practices. Ogbu, in an essay titled "Political wills and war against corruption" agrees with this assertion when he writes that:

\begin{abstract}
... an Abuja High Court deals a fatal blow to the code of conduct mechanism for fighting corruption when it held without justification, that the code of conduct mechanism is subject to the immunity clause. The pronouncement of the Supreme Court in Yusuf v. Obasanjo may contribute to the breeding of corruption in Nigeria's electoral process. In the Yusuf case, the appellants had sought to join corporate Nigeria (limited by Guarantee) as a party to the election petition for its donation of N2 billion to President Obasanjo contrary to section 221 of the Constitution. The Supreme Court, in refusing the application for joinder, held that the donation is not a corrupt act and does not amount to undue influence...
\end{abstract}

This ruling by the apex court was quite unfortunate and damaging for the image of the judiciary. The above analysis portrays the judiciary as not only compromising of law but laying dangerous precedents for corrupt practices to strive in Nigeria.

There have been cases of purchases of judgments by litigants especially at the election petition tribunals. It has been established that judges that go to these tribunals come back as multi-millionaires. Agba (2010) writing under the caption "How the Judiciary Aids Corruption" said, "...Eso knows what is talking about. He once headed a panel that unraveled high level corruption in the judiciary. That panel recommended 47 judges for sack..." The case of the President of the Court of Appeal against the Chief Justice of Nigeria epitomizes the level of corruption in our judicial system. In this case, the President of the Court of Appeal alleged that the Chief Justice of Nigeria asked him to ensure that the election petition tribunal was composed in a way that will favour the Sokoto State Governor.

\title{
2.3 Bid-Rigging
}

Bid-rigging falls under public administration and corruption in public administration results in the inefficient provision of services. It violates a basic principle of republicanism regarding the centrality of cultic virtue.

The issue of bid-rigging came to the fore-front in the Senate investigation of the sale of public enterprises by the BPE. During the investigation which started on $8^{\text {th }}$ August, 2011, it was disclosed that even companies that did not go through the bid process ended up buying some enterprises. This is a serious breached of due process. Bid-rigging is a breach and contravention of the Public Procurement Act. Under the Act, there are procedures laid down to be followed in the procurement of goods for government and every government institution or establishment.

Bid-rigging is a recent phenomenon adopted by creative and fertile minds of pubic functionaries to make nonsense of the Public Procurement Act. It really started during the regime of Obasanjo in 1999 though its history as a public policy dates back to the 1960 s.

\subsection{Contract Inflation and Kick-backs}

The concept of contract inflation and kick backs in Nigeria dates back to the 1960s. This started during the era of General Yakubu Gowon when the policy of rehabilitation and reconstruction was adopted. During this time, there was massive construction works in Nigeria. Indeed, most of the roads and national structures in the country were built during that era. The construction jobs were given out as contracts.

It is through the process of awarding the contract that it is inflated, that is, there is an increase in the actual amount quoted or estimated as the cost of the contract. The additional amount or fund added to the actual contract sum is the inflated sum. The inflated sum is usually given to the government officials that award the contract.

Kick backs on the other hand is euphemism for bribe. A kick back is official's share misappropriated funds allocated from his organisation to another involved in bid rigging. Government functionaries collect certain percent of the contract sum as kick backs. This ranges between five percent to twenty five. Kick backs is the major reason for most substandard jobs that we have in Nigeria. The reason for this is because the companies after paying kick backs resort to lowering standards. This accounts for the non-durability of our roads and the collapse of public buildings. The reasons for these are that these jobs are never done with agreed specifications. Again, sub-standard materials are used. The contractors get away with all these because the people that would have inspected or certified the payment have all been 
compromised through kick backs.

Contract inflation constitutes a serious drain in our national resources. Also, contract inflation is the sole reasons for the high reason for the high cost of government projects. Some of these projects are usually reevaluated to increase or inflate the cost. Ribadu declares:

...These are just two examples in 50\% of the grand corruption that takes place in Africa, the money is kept somewhere else, enabled by systems of poor regulation that allow abuse by looking for ways to profit.

\subsection{Bribery}

Bribery has been defined as an offer or promise of money for advantages in return for benefits that are under the discretion of a public officer or official. In Nigeria, legally attempting, providing, giving, soliciting or accepting a bribe is considered as an offence that carried with it either criminal or civil liability. Bribery by implication is a corrupt act that violates a public servant's responsibilities to the members of the public. It involves the violation of public trust. It encourages unfair or undeserved benefit or advantage (Ogbu, 2011). Bribery can also be successful if there exists a trust between the giver and receiver. This therefore makes bribery a joint activity that involves two sides of a transaction.

Atimes, it is very difficult to distinguish between a bribe and a gift. This can be seen in the case of Petroleum Minister during the military era. Professor Tam David West was given a gold writ watch, which was later considered as a bribe but he took it as a gift. It is on the basis of this confusion that certain criteria have been established to distinguish between a gift and a bribe. One of such criterion includes openness, freedom and good feeling by both parties. Both parties must be happy abut the exchange to distinguish a gift from bribe. But where there are elements of secrecy, coercion and obligation, such is considered as a bribe and not a gift. Here the parties involved in in the exchange are motivated by a gain that results from such exchange. Bribe therefore is a transaction in which future gain is expected from the receiver.

In Nigeria, bribery is a very common form of corruption that occurs at most every second and every where. This includes public and private sectors of the economy. The Nigerian Police is one public outfit that bribery is seen as a way of life. This is institutionalized in the Police as the police men and women in bribery activities openly indulged in this unwholesome act. It is as a result of this pervasiveness of bribery that the international community has been advocating for countries to dissociate and incriminate as separate offences, active and passive bribery. Active bribery is defined for instance as the promising, offering or giving by any person, directly or indirectly, of any undue advantage (to any public official), for himself or for anyone else for him to act or refrain from acting in the exercise of his functions (Article 2 of the Criminal Law Convention on Corruption (ETS 173) of the Council of Europe. Passive bribery is on the other hand, viewed as the request or receipt by public official directly or indirectly or any undue advantage for himself or for anyone else or the acceptance of an offer or a promise of such an advantage, to act or refrain from acting the exercise of his functions (Article 3 of the Criminal Law Convention on Corruption (ETS 173).

\subsection{Fraud}

Fraud is one common corrupt practice. This happens in Nigeria regularly where people resort to it to gain illegal and unearned income. Fraud is viewed as an act of misrepresentation or deception. This includes charging for goods or services never delivered, changing the specifications or timing of goods and services and their expiration dates, or even overpricing goods and services in order to cover the cost of bribes is considered as fraud. Fraud results in the loss of state revenue. In Nigeria the loss of revenue through fraudulent activities run into about forty billion dollars annually (Tell, 2010).

Fraudulent activities occur both in private and public sectors. The private sector involvement in fraud is to gain illegal and extra unnamed income through changing the contents of documents or providing incorrect information and documents. In the public sector, fraudulent activity is through overlooking altered or missing documents or by receiving bribes to ignore illegal activity or practice.

There are different kinds of fraud. Fraud occur in customs through the under or over declaration of the value of goods or misclassification.

There is also electoral fraud, which is usually carried out by politicians with the active connivance with electoral officials. This involves illegal interference with the process of an election. Acts of fraud affects vote contents to bring about an election result, through either increasing the vote share of the favoured candidate, depressing the vote of the rival candidate or even both. The mechanism of electoral fraud includes illegal voter registration, intimidation at polls, and 
improper vote counting and collation of election results.

\subsection{Embezzlement}

Embezzlement, which is the outright theft of entrusted funds by public officers, is a very common corrupt practice in Nigeria. This involves the misappropriation of property or funds.

\subsection{Nepotism and Cronyism}

Nepotism and cronyism, implies favouring of relatives (nepotism) or personal friends (cronyism). So, when relative or personal friends are favoured by an official, it is a form of illegitimate private gain. Nepotism and cronyism may be combined with bribery. In Nigeria, we have a reported case of a former Minister of the Federal Territory, Mallam El Rufai, who allocated choice government land in the Federal capital to his wife and children. Also, the former President, Olusegun Obasanjo has been accused of influencing the sales of government enterprises to his close associates.

Nepotism and cronyism are common corrupt practices in Nigeria, which has not been viewed seriously. For instance, in Delta State, the former Governor, James Ibori appointed his blood cousin as the Secretary to the State Government. The present Governor Dr. Emmanuel Uduaghan is a blood relation of the former Governor. In Cross River State, a one time Governor of the state Clement Ebri had most of his appointees selected only from the former students of University of Nigeria, Nsukka. This included even his Deputy and Ebri was a product of that University too. This is a milder form of cronyism.

Indeed, privatization, which involves the sale of government owned property, is particularly at risk of cronyism. This is because, those with political connections unfairly gained large wealth, as can be seen in the ongoing Senate investigation of the Bureau of Public Enterprises (BPT).

\section{Reasons for Corruption in Nigeria}

The basic question to be addressed here is what are the reasons for corruption? The imperative of this is hinged on the fact that the society as a whole, know that corruption is a social vice so, why indulge in it?

A response to this question will show that some people resort to corruption as the last option since it is the easiest way or the only way to get what they want. Also, a bribe may provide a wrongdoer with the sole option and a convenient means to avoid punishment. Several politicians, police and judges seem to ignore corruption and even practice it themselves.

It has been argued that corruption in a country is an indicative of the failure of government. It reveals that there is a great deal of uncertainty in the market place and that rules and regulations are vague and constantly changing. It indicates the fact that public policies are implemented inefficiently and incompetently. These conditions make it easier for private citizens and public officials to benefit personally. These hold true to the Nigerian situation as far as corruption is concern.

Also, in Nigeria and other countries corruption exists because of certain tradition, custom, economic conditions, government or social disorder. One of the basic reasons for corruption in Nigeria has been attributed to the scandalous low pay received by public servants and the ambiguity of some laws that aid public servants to interpret these laws as they wish. So, overworked public servants also may ask for bribe to speed up process. This system enables an inefficient bureaucracy to work faster (Wikipedia, 2011). Dike (2010) argued hat the culture value system, polygamous households, extended family system, lacking of effective control of taxing systems, poor reward system, lukewarm attitude of officers enforcing the laws, poverty and income inequalities are some of the reasons for corruption.

Traditionally, and in most customs in Nigeria, individuals are accorded respect and recognition not base on integrity, honesty, academic excellence and high moral values but on the financial strength or material affluence and acquisitions. It is only those who have made it materially and financially that are honoured with chieftaincy titles. It is not how much you have advanced and promoted the course of your people that earned people honour and respect in Nigeria but how much you have in your pocket. It is on the basis of this that most people resort to corrupt activities to make it big and fast.

Again, some customs in Nigeria like the Igbos and Yorubas are very mercantilist and materialistic. For instance, among the Igbos of eastern Nigeria, there exists open competition for wealth.

The allure for material wealth among Nigerians has therefore killed social values and ethics of honesty, integrity, 
trust, good conscience and good name. Now, it is only money that gives one a reputation and a "good name". This decay in social values and ethics is worsened by the prosperity gospel pioneered by Pentecostalism in Nigeria. Even within the church (es), it is only the rich that are constantly being administered and cared for by the clergies.

With societal rejection and castigation of those that failed to use their official position to enrich themselves, it becomes psychologically challenging to make it by all means. So, there is also the psychological needs satisfaction angle to why corruption strives in Nigeria. The psychological trauma of being seen as a failure and unsuccessful is one of the motivational bases of corruption in Nigeria. The social demand on every member of the Nigerian society necessitates and excites corruption tendencies in most people. This can be seen in the culture of the extended family system where the entire family looks up to you as the bread winner.

In Nigeria, the socio-economic outlook of the ruling elites reflect what can be termed the western or neo-liberal philosophy. Claud Ake views morality or social values from this perspective when he says as quoted by Olorode:

\footnotetext{
... the autonomy of morality of social values is more apparent than real contemporary western morality condemns theft.

And we forget that theft as a moral value is something created and dependent on particular economic condition. Where there is no scarcity and no private property, the idea of theft will not arise.
}

To Olorode (2011), the entire business of the neo-liberal social and economic philosophy revolves around "the market forces theology, roll back of welfare states, shrinking the public sector, (sacking of workers), cost recovery on social services (healthcare, education, housing etc) and accounting of public property (privatization), promotion or consultants, contractors etc" is basically the reasons for current socio-economic crisis and create fertile ground for corruption.

Furthermore, the psychology of corruption has been anchored among traditional rulers, religious leaders, intellectuals and even student leaders. This is achieved through the imposition of all sort of ephemerals on public consciousness creating the "messiah, magic wand" and related syndromes in public consciousness and institutionalizing moral and psychological corruption.

\section{Effects of Corruption in Nigeria}

Corruption is a social problem that hobbles development and robs it people of opportunities for any meaningful economic and social advancement (Ezekwesili, Ibrahim and Naido, 2011). It is a cancerous activity that fights against society and its growth. It leads to the undermining of public trust in public institutions and disproportionately affects the poor who cannot afford the payment of bribes to obtain public services. Through the distortion of government decision-making, it leads to wasteful investment projects, non-competitive and the uneconomic allocation of public funds.

Corruption in concrete terms highlights the fact that the public generally is not aware of what benefits an ethical system could provide for all. Bribes increase the income of public servants. But when payments are legally made, such funds go to the public treasury for the benefits of all.

Corruption distorts public choice in favour of the wealthy and the powerful. It reduces the ability of the state to perform its statutory duties of providing social services such as health, education and good transportation system. When these services are not provided, the result will be underdevelopment.

Again, corruption have the potentials and capacity to restrict investments, slow down economic, social and political development, as it endangers democratic values and increases distrust among the citizenry and investors. It also increases the chances of instability in society since corrupt political leaders are often times under constant threat of being removed or overthrown. This accounts for the instability experienced in Nigeria within the past five decades. The choices in a corrupt regime or administration are always economically inefficient.

Generally, corruption according to Wikipedia (2011) leads to increased cost and reduction of product and service quality, satisfaction and false demands.

The focus of most studies has been on the economic effects of corruption, but it is an established fact that the poor bear a considerable and usually disproportionately share of the burden of corrupt activities. The poor may be out rightly excluded when access to public goods and services required bribe. With their lack of voice and political influence, in some instances, the poor may be made to pay more than the people with higher incomes. Though richer households are more likely to pay bribes, the burdens of corruption that is measured as the fraction of income paid in bribes are much greater for the poorer households.

Corruption hurts the poor disproportionately and increase income inequality since it permits particular individual or groups of individuals to take advantage of state activities at the cost of the rest of the population. For instance, when 
corruption leads to shoddy public services, the poor have no alternatives or options since they cannot turn to the private sector, such as private schools, hospitals, security or garbage collection. In Nigeria, the public schools and hospitals are for the poor masses. The children of all the public figures are in private schools or are sent abroad where there are no interruptions of academic calendar due to avoidable incessant strike actions.

Dike (2010) in an article title "Managing the Challenges of Corruption in Nigeria" states that corruption leads to waste of skills since precious time is wasted in setting up committees to fight corruption and monitor projects abandoned by "unscrupulous politicians and contractors".

Indeed, corruption is destructive of Nigeria corporate image. This can be seen in the ranking of Nigeria as the second most corrupt country in the world. Also, corruption increases illiteracy rate in the country due to the incessant strikes by teachers and other staff. Again, due to the poor remuneration of the teachers, the standard of education has been seriously affected in the country.

\section{Present Anti- Corruption Strategies in Nigeria}

Dike (2010) states that the "unending claims of corruption - fighting omissions in the society includes the Code of Conduct Bureau, and the Independence Corrupt Practices and other related offences Commission (ICPC), the Police, Central Bank and the Court of Justice". There is the need to take historical perspective to what some regimes have attempted to do in terms of strategies to combat the menace of corruption. This approach will establish a link between the past and the present thereby making it possible for us to have a better idea of the weaknesses of these strategies.

Past Nigerian governments have experimented with social reform policies aims at ridding the Nigerian polity of corruption. Such policies include President Shehu Shagari's "Ethical Revolution," Military President, General Ibrahim Badamosi Babangida's, "Mass Mobilization for Social and Economic Reconstruction" (MAMSER), The General Muhammadu Buhari and Brigadier General Tunde Idiagbo's" War Against Indiscipline (WAI), General Sani Abacha's National Orientation Agency (NOA) and President Olusegun Obasanjo's "War Against Corruption." This anti-corruption crusades and the so-called reforms have been the fulcrum of the economic and social policies of the last twelve years of the nation's democratic rule. These policies on the surface are very attractive but they were anchored according to Olorode (2011) on an economic foundation that ran contrary to the hallowed principles of public morality.

The reason for the glaring contradiction has been traced to the illegitimacy of the ruling circles, this agencies and mentors like the International Monetary Fund (IMF) and the World Bank. This accounts for propaganda, obfuscation and media grand - standing linked with such deceptive policies. It is on the basis of this that such propaganda failed to sustain these policies and manufacture legitimacy for them. So, the failure of the previous strategies failed largely due to deceptive mechanism, behind their conception and formation.

The Code of Conduct Bureau is the only constitutionally established anti-corruption agency in Nigeria. This Bureau was established to combat corruption among the public servants. But recent revelations by one of the Commissioners showed that the Bureau never had a full complement of Commissioners and as such was technically in the legal sense handicapped to perform its statutory functions.

Again, the Supreme Court pronouncement in Nwankwo V. Nwakwo, which states that a private person has no locus standi to prosecute the contravention of the Code of Conduct present another legal jack on the neck of the Bureau in the discharge of the statutory duties.

Section 35 of the 1995 draft Constitution would have solved this problem but the 1999 Constitution for no just cause did not include this noble section which states that, every person shall have the right to;

(a) Ensure the eradication of corrupt practices and abuse of power;

(b) Protect and preserve public property

(c) Fight against misappropriation and squandering of public funds.

The Public Complaint Commission was established to receive complaints about official corruption and other unethical conducts of public officials. The Commission has not achieved any reasonable thing to justify its establishment and the huge budgetary allocation given to it. The Commission is indeed moribund and cannot stand the clinical approach to modern corrupt practices in Nigeria.

The Independent Corrupt Practices and other related offences Commission (ICPC) and the Economic and Financial Crime Commission (EFCC) are products of the Acts of parliament. There are statutorily empowered to investigate corruption in both public and private sector respectively. The ICPC is to investigate all public officials of any corruption and related offences; the EFCC is to investigate both the public servants and private individuals of all economic and financial crimes. 
The ICPC has been very thorough but very sluggish in its approach in the discharge of its statutory duties. It has few cases to its credits but without pursuing any to its logical conclusion. This approach of the ICPC has been attributed to the maturity of the hierarchy of the Commission who has been retired Judges. So, the idea of assuming that the accused is innocent until proven guilty by a competent court holds sway and is guiding principles in its operation. On the other hand, the EFCC as an agency in Nigeria has been more active. This is more so, because of the number of cases the Commission has been able to investigate and handle. Again, the EFCC successfully investigated and prosecuted an Inspector General of Police, former Governors and Minister of Education. These cases proved that the EFCC have the commitment to fight corruption in Nigeria.

This, however has not deterred Nigerians and even foreign government of questioning the efficacy of the EFCC anti-corruption campaign. Ogbu (2011) put it thus:

Yet many Nigerians see the anti-corruption drive as highly selective, focused on the President's enemies or the politically expendable and doing little to address institutional failings. An anti-corruption Commission set up by President is yet to bring a successful high profile prosecution.

Olorode (2011) also share this sentiment when he writes:

The evidence before many Nigerians is to the effect that so much doubt exists about the character, procedures, sustainability and honesty of anti-corruption and related crusades." But they are enjoying the showmanship and grandstanding. Even the oversee guarantors of the ruling regimes in the last eleven years have denigrating views about the economy, security and sincerity of the anti-corruption crusades.

Due largely to the nature of the war in the ruling class, the mediating agencies in the anti-corruption crusade tend to operate with strategic selectivity. This appears to be a political necessity as can be seen in the response to a mail sent to the concerned Ngeriangroup@yahoogroups.com by editor@grapwatch.com on Saturday 13 $3^{\text {th }}$ January, 2-7 where it was asked why Obasanjo was not probed, the Chairman of EPC, replied asking EFCC to probe Obasanjo was like asking EFCC to pack up and go home. A display of brilliance here one would say. This strategic selectivity can also be reflected in the theory and historicism of the anti-corruption crusaders.

\section{The Way Forward}

From our analysis, it is clear that there has been no political will to fight corruption by various Nigerian governments. It is that lack of political will that has made the various anti-corruption strategies to fail. The reason for this is anchored on the fact that no anti-corruption mechanism or strategy can succeed without a strong leadership and political will. So, what Nigeria needs to overcome corruption is a strong leadership with a political will that will both set an example and demonstrate in concrete terms that no one is above the law. Except there is a clear and unambiguous signals of support emanating from the top, those charge with the responsibility of administering and enforcing the crucial aspects of the nation's integrity system may feel inhibited. It is therefore clear that political will is a critical and a basic starting point towards the achievement of a sustainable and effective anti-corruption strategy.

According to National Anti-corruption strategy and Action Plan for Tanzania, political will involves building legitimacy, credibility, and broad-based political support and compliance both in society and within government. Political will according to Ogbu (2011) broadly conceived, involves leaders in all spheres of life, political leaders, professional groups, the private sector, trade unions, religious institutions, and other civil society groups etc. However, our advocacy here mainly focuses on the executive, legislative and judiciary arms of government. These arms of government must have the political will to combat corruption.

Furthermore, there is the need to bring about stronger rules and procedures that will make corruption unattractive in the country. The case where a person is found guilty of corruption to the tune of several billions of dollars and naira and there is only three or six months jail term or a plea bargain where you are kept in specialist private hospitals will only encourage people to loot the public treasury with the thinking that whenever they are call to answer questions, they have nothing serious to loose. The case of Bode George and Cecilia Ibru are cases that will encourage people to be more corrupt.

Again, there is the need to eradicate poverty in the land and redistribute the wealth of the nation. There should be a conscious effort to bridge the gap between the rich and the poor.

There is also the urgent need to introduce a course like the psychology of corruption in our tertiary institutions. But from the primary to secondary school, there is the need to teach the pupils and students about the negative effects of corruption. 
Also, the religious institutions can do much to preach the gospel of humility, chastity, honesty, truth, sincerity and uprightness. There is need to promote the moral virtues of Jesus Christ rather than this gospel prosperity. Holiness should be redefined and virtue as a necessary doctrine of all religions.

The police which have been identified as the most corrupt institution in Nigeria should be restructured. There should be an upward review of the police salary structure in line with the importance of their jobs and as an anticorruption institution. Their salary should make bribery unattractive as anyone caught within the police force in any corrupt act should be prosecuted, dismissed and jailed.

There is also the need to strengthen the security operation in the country. This is because there cannot be any meaningful development where there is insecurity.

There should be laws that clearly defined corrupt activities and conflicts of interest. There should be law enforcement against the bribe giver and taker.

All public officials and members of their families should be banned from patronizing private institutions such as schools and hospitals.

Public officers apart from declaring their assets, their family members' asset must also be declared. This should be done while in office and after leaving office. There should be an efficient performance evaluation system in pubic service and establish incentives for good performance. All these when put into effective practice will go a long way to reduce corrupt activities and Nigeria image will be redeemed without the propaganda of rebranding.

\section{References}

Awuzie, U. (2011). Press Statement at the end of National Executive Council Meeting of Academic Staff Union of Universities held at ABU, Zaria, 5-16 May, 2011.

Ayoade, A. A. (2011). "The Audacity of Corruption" In The National Scholars, vol. 8, No. 1, pp 38-40.

Dike, V. E. (2010). "Managing the Challenges of Corruption in Nigeria." Centre for Social Justice and Human Development, Sacramento, California.

Ekanem, S. A. (2010). How the Military Underdeveloped Nigeria, Calabar: University of Calabar Press.

Faseke, M. (2010). "Corruption and the Image of the Nigerian Civil Service: A historical Discourse". The Constitutions. A Journal of Constitutional Development, Centre for Constitutionalism and Demilitarization, pp 101-111.

Newswatch Magazine, August 30, 2010.

Ogbu, O. N. (2011). "Political will and War Against Corruption" In The National Scholars. Vol. 8, No. 1, June, 2011, Pp 24-29.

Olorode, T. (2011). "The Political Economy of Corruption in Nigeria" In The National Scholars Vol. 8, No. June, 2011, Pp 6-11.

Ribadu, N. (2009). "Capital Loss and Corruption: The Example of Nigeria Testimony before the House Financial Services Committee, USA, in Anti-corruption Laws, Abuja: Panaf Press, pp 151-160.

Tell Magazine, No 20 May 24, 2010.

Tell Magazine, No. 22, June 7, 2010.

Tell Magazine, No. 25 June, 28, 2010.

Tell Magazine, No. 38, September 27, 2010.

Wikipedia, Free Encyclopedia 
